\title{
PENGARUH IKLIM ORGANISASI TERHADAP BURNOUT PADA PERAWAT RUMAH SAKIT DI LEBAK DALAM MASA COVID-19
}

\author{
Fera Verentina Marpaung, Endro Puspo Wiroko, Seta Wicaksana \\ Fakultas Psikologi Universitas Pancasila \\ E-mail: miteaung@gmail.com, endro.puspowiroko@univpancasila.ac.id, \\ seta.wicaksana@gmail.com
}

\begin{abstract}
This study aims to find effect from organizational climate to burnout in hospital nurses in Lebak during the COVID-19. Nurses who worked during the COVID-19 were at the forefront of cutting infected tissues and this resulted in quite high suffering. The main fatigue is emotional or better known as burnout. One of the causes of burnout is organizational climate. A high organizational climate can produce a positive work environment so that nurses don't feel a threat at work. Respondents in this study were nurses who worked at the hospital in Lebak as many as 177 respondents who were selected through purposive sampling technique. The measuring instruments used in this research were CLIOR Scale Short Version and Maslach Burnout Inventory. The results of the calculation of the regression analysis technique show that the significance value is 0.283 ( $p>0.05$ ). This means that there is no effect from organizational climate to burnout in hospital nurses in Lebak during the COVID-19.
\end{abstract}

Keywords : Organizational Climate, Burnout, Nurse, COVID-19

\begin{abstract}
ABSTRAK
Penelitian ini bertujuan untuk melihat pengaruh iklim organisasi terhadap burnout pada perawat rumah sakit di Lebak dalam masa COVID-19. Perawat yang bekerja dalam masa COVID-19 ini menjadi salah satu garda terdepan bagi pemutusan jaringan tertular dan hal tersebut mengakibatkan kelelahan yang cukup tinggi. Kelelahan yang paling utama adalah secara emosional atau lebih dikenal dengan istilah burnout. Salah satu penyebab terjadinya burnout adalah iklim organisasi. Iklim organisasi yang tinggi dapat menghasilkan lingkungan kerja yang positif sehingga perawat tidak merasa adanya ancaman dalam bekerja. Responden dalam penelitian ini merupakan perawat yang bekerja di rumah sakit di Lebak sebanyak 177 responden yang dipilih melalui teknik purposive sampling. Alat ukur yang digunakan dalam penelitian ini adalah CLIOR Scale Short Version dan Maslach Burnout Inventory. Hasil perhitungan teknik analisis regresi menunjukkan bahwa nilai signifikansi sebesar 0.283 ( $\mathrm{p}>0.05)$. Hal tersebut berarti tidak terdapat pengaruh iklim organisasi terhadap burnout pada perawat rumah sakit di Lebak dalam masa COVID-19.
\end{abstract}

Kata kunci : Iklim Organisasi, Burnout, Perawat, COVID-19

\section{PENDAHULUAN}

Situasi dunia dalam penyebaran covid19 sedang merajalela, dengan kasus positif dan kasus kematian yang melonjak. Menurut
Worldometers hingga bulan Mei 2020 dalam skala dunia, ada sekitar 6.734.384 kasus dengan 393.752 di dalamnya adalah kasus 
kematian. Penyebaran covid-19 yang terbilang cepat khususnya di Indonesia sendiri, dimana dilansir melalui web resmi Gugus Tugas Percepatan Penanganan Covid19 bahwa data sampai Agustus 2020 terkonfirmasi positif covid-19 sebanyak 137.468 dengan kasus kematian sebanyak 6.071. Dengan adanya wabah berbahaya yang menyerang dalam skala dunia ini, mempengaruhi kehidupan secara luas. Salah satu yang paling dipengaruhi dalam kehidupan sehari-hari adalah bekerja. Pengaruh dari wabah ini dirasakan oleh semua lapisan masyarakat khususnya di Indonesia. Tenaga kesehatan salah satunya yaitu perawat menjadi garda terdepan bagi pemutusan jaringan tertular covid-19 ini. Perawat yang turut merasakan dampaknya secara langsung karena pada dasarnya ini adalah salah satu tugas yang harus dipenuhi. Sama halnya dengan pernyataan yang dikeluarkan oleh WHO (World Health Organization) bahwa dengan adanya covid19 ini menjadi pengingat dari vitalnya peran perawat. Perawat menjadi momok pembicaraan dalam perkembangan kasus covid-19 ini, sehingga banyak pula media yang menyoroti kasus-kasus yang berkaitan dengan perawat dalam masa covid-19 ini. Menurut Pusat Penelitian Kependudukan dalam LIPI, mengatakan bahwa PPNI menyebutkan hingga Mei 2020 sudah ada 20 orang perawat yang meninggal dunia. Salah satu penyebab dari banyaknya kasus kematian perawat dalam hal ini karena kelelahan yang dialami selama penanganan pasien dalam masa covid-19. Kelelahan yang dialami bukan hanya kelelahan fisik namun secara emosional. Jika dipaksakan untuk terus bekerja, kelelahan emosional akan semakin bertambah dan dapat mengganggu kelancaran pekerjaan bahkan dapat memberikan dampak yang buruk bagi kesehatan pekerja itu sendiri (Suma'mur, 2009). Kelelahan emosional ini erat kaitannya dengan burnout. Burnout dinyatakan sebagai sindrom kelelahan emosional, depersonalisasi dan reduced personal accomplishment yang terjadi pada individu yang melakukan pekerjaan dalam memberikan pelayanan kepada orang lain dan sejenisnya (Maslach \& Jackson, 1996). Burnout ditandai dengan gejala-gejala yang berkembang karena periode stres kerja yang berlarut-larut (Maslach 1993). Hoskins (2013) menyatakan bahwa perawat yang mengalami burnout beresiko melakukan kesalahan yang berpotensi merugikan pasien. Perawat yang mengalami burnout dalam masa covid-19 ini selain dapat membahayakan pasiennya namun juga dapat membahayakan perawat itu sendiri. Burnout disebabkan oleh beberapa faktor seperti faktor individual dan situasional (Maslach, Schaufeli dan Leiter, 2001). Menurut 
Cherniss (1987) gaya kepemimpinan, kekuatan struktur dan iklim organisasi pun dapat mempengaruhi burnout pada tingkat individu. Burnout dapat muncul ketika lingkungan kerja yang tercipta tidak sesuai dengan standar harapan individu itu sendiri. Lingkungan kerja ini tergambar dalam iklim organisasi. Triguni (2000) mendefinisikan iklim organisasi sebagai pandangan atau persepsi terhadap kondisi kerja yang tercermin dalam sikap, perilaku, kepercayaan, cita-cita, pendapat dan tindakan yang mendorong sumber daya manusia terlibat dalam organisasi untuk bekerja. Iklim organisasi kaitannya dengan burnout ini mendapat perhatian dalam berbagai penelitian. Seperti pada penelitian yang dilakukan oleh Sahrah (2018) yang menunjukan bahwa adanya hubungan negatif antara iklim organisasi dengan burnout. Hal tersebut berarti semakin tinggi tingkat iklim organisasi maka semakin rendah tingkat burnout. Selanjutnya penelitian oleh Asi (2014) menemukan bahwa iklim organisasi berpengaruh secara langsung dan negatif terhadap munculnya burnout. Iklim organisasi menjadi sangat penting bagi keberlangsungan proses bekerja seorang perawat. Penciptaan iklim kerja yang positif adalah kunci keberhasilan dan kemajuan organisasi dan sangat penting untuk mencapai pekerjaan terbaik (Kassem dan Gaber, 2015).
Iklim organisasi yang tinggi atau positif dapat berpengaruh terhadap tingkat burnout pada perawat dalam masa covid-19 ini. Menurut Kusnanto (2003) perawat adalah seorang profesional yang memiliki kemampuan, tanggung jawab dan kewenangan melaksanakan pelayanan/asuhan keperawatan pada berbagai jenjang pelayanan keperawatan. Tugas perawat berdasarkan lokakarya yang diterbitkan pada tahun 1983 yaitu menyampaikan rasa hormat kepada pasien, memberi penjelasan kepada pasien, menghargai pasien, berkomunikasi yang berorientasi pada pasien, tidak menghina dan memahami pasien. Kenyataannya, perawat harus melakukan tugasnya meski dalam keadaan apapun salah satunya adalah dalam keadaan bahaya penyebaran wabah covid-19 ini. Pemenuhan tugas ini pun dapat menjadi salah satu penyebab perawat mengalami burnout. Berkaitan dengan hal tersebut, di salah satu daerah yaitu Lebak memiliki jumlah kasus covid-19 yang di tampilkan oleh Pemerintah Kabupaten Lebak (https://siagacovid19.lebakkab.go.id/data) dimana ada sebanyak 674 orang dengan 29 orang yang terkonfirmasi positif covid-19. Dalam penanggulangannya, Lebak telah mempersiapkan 10 posko penjagaan di perbatasan dalam upaya pencegahan keluar masuknya warga dari luar kota. Dinas Kesehatan Kabupaten Lebak pun telah 
melaksanakan Drive Thru Rapid Test yang juga mengikuti protokol kesehatan yang diberlakukan. Dalam satu kesempatan, Bupati Lebak yaitu Ibu $\mathrm{Hj}$. Iti Octavia menyebutkan bahwa perawat merupakan ujung tombak pelayanan kesehatan terhadap masyarakat yang diikuti pula dengan pernyataan bahwa Lebak masih kekurangan perawat bahkan berkisar 400-600 orang. Berdasarkan pernyataan Bupati Lebak tersebut, perawat yang karena populasinya masih kurang, juga dimana dalam kasus covid-19 ini peran para perawat sangatlah penting. Perawat dapat bekerja lebih padat dari biasanya sehingga akan membuat para perawat merasa cepat lelah. Pekerjaan padat ini berkaitan dengan beban kerja perawat. Menurut buku tulisan Suzanne Waddil-goad yang berjudul Nurse Burnout, bahwa salah satu penyebab terjadinya burnout pada perawat adalah beban kerja dan tekanan waktu yang tinggi. Jika hal ini semua dirasakan terus menerus dan berkepanjangan maka akan menimbulkan stres. Salah satu penyebab munculnya stres kerja yang tinggi adalah iklim organisasi yang tidak sehat (Robbins, 2008; Wagner dan Hollenbeck, 2010; Luthans, 2011; Gibson et al., 2012). Iklim organisasi yang tinggi atau positif dapat meminimalisir terjadinya burnout kaitannya dengan faktor- faktor yang menjadi penyebab munculnya burnout itu sendiri. Lebih lanjut, dalam hal ini berkaitan dengan situasi dan kondisi yang berbeda dari sebelumnya, adanya situasi covid-19 ini membuat Rumah sakit lebih memperhatikan iklim organisasi yang ada demi terjaganya lingkungan yang positif sebagai salah satu yang dapat meminimalisir munculnya burnout dalam tingkat individu. Dalam penelitian ini, dimana ingin melihat apakah iklim organisasi mempengaruhi tingkat burnout pada perawat rumah sakit di Lebak dalam masa covid-19 ini.

\section{METODE}

Responden Penelitian. Responden dalam penelitian ini adalah perawat yang bekerja di rumah sakit di Lebak dalam masa covid-19 dengan masa kerja 1 tahun di rumah sakit saat ini. Responden yang digunakan dalam penelitian ini berjumlah 177 sesuai dengan perhitungan Tabel Isaac and Michael dimana populasi sebanyak 360 orang dengan signifikansi $5 \%$.

Desain Penelitian. Penelitian ini merupakan penelitian kuantitatif dengan desain analisis regresi. Teknik pengambilan sampel yang digunakan yaitu purposive sampling.

Instrumen Penelitian. Penelitian ini menggunakan dua alat ukur yang diadaptasi oleh peneliti. Alat ukur iklim organisasi yaitu CLIOR Scale Short Version yang berisi 15 
item dengan mengikuti perkembangan dan pedoman psikometri terbaru (Asosiasi Penelitian Pendidikan Amerika, Asosiasi Psikologi Amerika \& Dewan Nasional tentang Pengukuran). Alat ukur ini menggunakan skala likert dengan 4 pilihan jawaban yaitu 1 = Sangat tidak setuju, $2=$ Tidak setuju, 3 = Setuju dan 4 = Sangat setuju. Alat ukur yang digunakan untuk burnout yaitu Maslach Burnout Inventory (MBI) yang berisi 22 item. Alat ukur ini menggunakan skala likert dengan 4 pilihan jawaban yaitu 1 = Sangat tidak setuju, 2 = Tidak setuju, 3 = Setuju dan $4=$ Sangat setuju untuk item favorable. Sedangkan untuk item unfavorable yaitu 1 = Sangat setuju, 2 = Setuju, 3 = Tidak setuju dan 4 = Sangat tidak setuju. Iklim organisasi merupakan aspekaspek yang dirasakan oleh anggota organisasi. Denison dalam Armstrong (2006) mengatakan bahwa iklim organisasi mengacu pada aspek- aspek lingkungan yang secara sadar dirasakan oleh anggota organisasi. Sedangkan burnout merupakan suatu keadaan dimana individu mengalami kondisi kelelahan secara emosional yang berlangsung dengan waktu yang cukup panjang dan menyebabkan perubahan sikap dan perilaku yang cenderung negatif.

Prosedur Penelitian. Tahap pengambilan data dalam kurun waktu 20 hari. Tahap pertama, dilakukan pilot study dimulai pada tanggal 5 Juli 2020 hingga 15 Juli 2020. Tahap kedua, dilakukan field study dimulai pada tanggal 16 Juli 2020 hingga 25 Juli 2020. Dalam penelitian ini, sebelum kuesioner disebar secara online, kedua alat ukur yang digunakan sudah melalui proses expert judgement oleh dosen pengampu yang telah disesuaikan. Setelah dilakukan expert judgement, dilanjutkan dengan menyebarkan kuesioner secara online mengingat situasi yang harus mematuhi protocol kesehatan. Setelah dilakukan penyebaran tahap pertama, kemudian dilanjutkan dengan uji validitas dan reliabilitas kedua alat ukur. Setelah memenuhi syarat uji validitas dan reliabilitas, kemudian dilanjutkan dengan pengambilan data tahap kedua. Terakhir, dilakukan uji asumsi klasik dan uji regresi.

Analisa Data. Alat ukur yang memenuhi untuk digunakan ketika sudah melewati proses uji validitas dan reliabilitas. Hasil dari uji validitas alat ukur iklim organisasi adalah terdapat 1 item yang gugur dari 15 item. Total akhir dari item alat ukur iklim organisasi adalah 14 item. Hasil uji validitas alat ukur burnout adalah terdapat 2 item yang gugur dari 22 item. Hasil uji reliabilitas pada alat ukur iklim organisasi didapatkan angka Cronbach's Alpha 0,804 (r $>0,7)$ yang berarti alat ukur ini dapat dikatakan reliabel. Selanjutnya, hasil uji reliabilitas pada alat ukur burnout di dapatkan 
angka Cronbach's Alpha 0,880 (r > 0,7) yang berarti alat ukur ini dapat dikatakan reliabel.

HASIL

Dalam penelitian ini, dilakukan uji deskripif, uji asumsi klasik yaitu uji normalitas dan homogenitas dan uji regresi. Berikut adalah tabel dari hasil perhitungan dalam penelitian.

Tabel 1. Gambaran Responden Menurut Usia

\begin{tabular}{ccc}
\hline Usia & $\begin{array}{c}\text { Frekuens } \\
\text { i }\end{array}$ & $\begin{array}{c}\text { Persentase } \\
(\%)\end{array}$ \\
\hline $20-25$ & 63 & 35.6 \\
$26-30$ & 79 & 44.6 \\
$31-35$ & 21 & 11.9 \\
$36-40$ & 13 & 7.3 \\
$41-45$ & 1 & 0.6 \\
\hline TOTA & 177 & 100 \\
L & & \\
\hline
\end{tabular}

Berdasarkan Tabel 1 diatas bahwa responden dalam penelitian ini paling banyak berada pada kategori usia 26-30 tahun sejumlah 79 orang (44.6\%), usia 20-25 tahun sejumlah 63 orang (35.6\%), usia 31-35 tahun sejumlah 21 orang (11.9\%), usia 36-40 tahun tahun sejumlah 13 orang $(7.3 \%)$ dan yang paling sedikit adalah usia 41-45 tahun sejumlah 1 orang $(0.6 \%)$.

Tabel 2. Gambaran Responden Menurut Jenis Kelamin

\begin{tabular}{ccc}
\hline Jenis & Frekuens & $\begin{array}{c}\text { Persentase } \\
(\%)\end{array}$ \\
\cline { 3 - 3 } Kelamin & $\mathrm{i}$ & \\
Laki-laki & 77 & 43.5 \\
Perempuan & 100 & 56.5 \\
\hline TOTAL & 177 & 100 \\
\hline
\end{tabular}

Berdasarkan Tabel 2 diatas bahwa responden dalam penelitian ini paling banyak berjenis kelamin perempuan dengan jumlah sebanyak 100 orang (56.5\%) dan berjenis kelamin laki-laki sebanyak 77 orang (43.5\%).

Tabel 3. Gambaran Responden Menurut Status Pernikahan

\begin{tabular}{ccc}
\hline $\begin{array}{c}\text { Status } \\
\text { Pernikahan }\end{array}$ & Frekuens & $\begin{array}{c}\text { Persentase } \\
(\%)\end{array}$ \\
\cline { 1 - 1 } $\begin{array}{c}\text { Belum } \\
\text { menikah }\end{array}$ & 72 & 40.7 \\
$\begin{array}{c}\text { Sudah } \\
\text { menikah }\end{array}$ & 105 & 59.3 \\
\hline TOTAL & 177 & 100 \\
\hline
\end{tabular}

Berdasarkan Tabel 3 diatas bahwa responden dalam penelitian paling banyak yang berstatus sudah menikah dengan jumlah sebanyak 105 orang (59.3\%) dan berstatus belum menikah dengan jumlah sebanyak 72 orang (40.7\%).

Tabel 4. Gambaran Iklim Organisasi

\begin{tabular}{ccc}
\hline Keterangan & Frekuensi & Persentase $(\%)$ \\
\hline Tinggi & 177 & 100 \\
\hline TOTAL & 177 & 100
\end{tabular}

Berdasarkan Tabel 4 dapat dilihat bahwa semua responden atau sebanyak 177 orang menggambarkan tingkat iklim organisasi yang tinggi.

\section{Tabel 5. Gambaran Burnout}

\begin{tabular}{ccc}
\hline Keteranga & Frekuens & $\begin{array}{c}\text { Persentase } \\
\text { n }\end{array}$ \\
\cline { 3 - 3 } i & $(\%)$ \\
Tinggi & 93 & 52.5 \\
Sedang & 34 & 19.2 \\
Rendah & 50 & 28.2 \\
\hline TOTAL & 177 & 100 \\
\hline
\end{tabular}

Berdasarkan Tabel 5 diatas bahwa responden pada kategori tingkat burnout yang 
lebih banyak adalah kategori tinggi dengan jumlah 93 orang (52,5\%), lalu kategori rendah dengan jumlah 50 orang $(28,2 \%)$ dan yang paling sedikit adalah kategori sedang dengan jumlah 34 orang $(19,2 \%)$.

\section{Tabel 6. Uji Normalitas}

\begin{tabular}{cc} 
Sig. & $\begin{array}{c}\text { Keteranga } \\
\mathbf{n}\end{array}$ \\
.061 & Normal \\
\hline
\end{tabular}

Berdasarkan Tabel 6 dapat dilihat bahwa nilai Sig. (2-tailed) antara iklim organisasi dan burnout adalah sebesar 0.061. Sig > 0.05. Maka sesuai dengan dasar pengambilan keputusan dalam uji normalitas Kolmogorov-Smirnov diatas, dapat disimpulkan bahwa data terdistribusi normal.

Tabel 7. Uji Homogenitas

\begin{tabular}{cc}
\hline Sig. & $\begin{array}{c}\text { Keteranga } \\
\mathbf{n}\end{array}$ \\
\hline .318 & Homogen \\
\hline
\end{tabular}

Berdasarkan Tabel 7 di atas diketahui bahwa data pada variabel iklim organisasi dan burnout memiliki varians kelompok yang sama atau homogen karena didapati nilai sig > .05.

Tabel 8. Uji Regresi

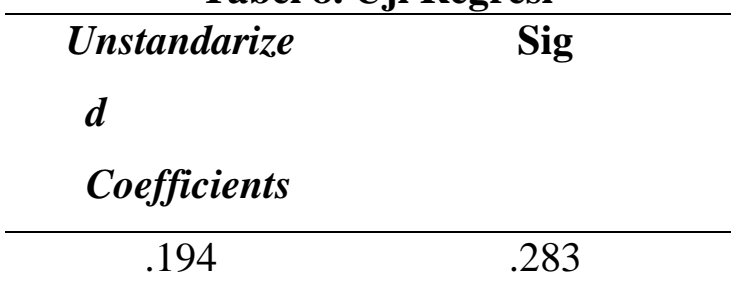

Berdasarkan Tabel 8 di atas uji regresi iklim organisasi terhadap burnout pada perawat dengan rentang usia 20-45 diperoleh nilai signifikansi sebesar .283 ( $\mathrm{p}>0.05$ ), maka dapat disimpulkan Ha ditolak. Hal ini berarti menunjukkan tidak ada pengaruh yang signifikan iklim organisasi terhadap burnout pada perawat rumah sakit di Lebak dalam masa covid-19.

\section{KESIMPULAN}

Dalam tahap pertama dan kedua di penyebaran data yang berlangsung selama 20 hari mendapatkan repsonden sebanyak 237 orang dengan pembagian data pilot study sebanyak 60 responden dan data field study sebanyak 177 responden. Dari 177 data responden diketahui bahwa lebih banyak responden perempuan, untuk usia terbanyak ada pada rentang 26-30 tahun dan dalam status pernikahan terbanyak adalah data yang sudah menikah. Gambaran iklim organisasi di rumah sakit Lebak terbilang tinggi dan gambaran burnout pada perawat di Lebak pun terbilang tinggi.

Berdasarkan hasil yang di dapat dalam penelitian ini, menunjukkan bahwa tidak ada pengaruh yang signifikan iklim organisasi terhadap burnout pada perawat rumah sakit di Lebak dalam masa covid-19 ini. Pengaruh iklim organisasi terhadap burnout hanya sebesar $0.7 \%$. Penelitian ini didukung dengan pernyataan yang dikemukakan oleh Madziatul (2011) bahwa burnout tidak hanya dipengaruhi oleh faktor-faktor lingkungan saja, tetapi juga dipengaruhi oleh faktor-faktor individual atau faktor internal, seperti tingkat stress, 
kemampuan bekerja, pengetahuan dan keterampilan yang dimiliki oleh seseorang.

\section{DISKUSI}

Dilihat dari hasil penormaan pada data mengenai iklim organisasi dan burnout bahwa nilai iklim organisasi tinggi dan nilai burnout pun tinggi yang berarti tidak memiliki pengaruh yang negatif seperti pada penelitian sebelumnya. Mengetahui ini, semakin jelas bahwasanya covid-19 sebagai situasi dan kondisi yang istimewa memberikan temuan yang berbeda. Burnout yang tinggi pada perawat di Lebak bukan disebabkan oleh iklim organisasi, karena secara data iklim organisasi Rumah Sakit yang ada di Lebak sangat tinggi. Hal tersebut berarti pihak Rumah Sakit telah memperjuangkan secara optimal bagaimana suasana, lingkungan dan aspek-aspek penting dalam menunjang kenyamanan, keamanan dan terhindarnya dari bahaya-bahaya yang tidak terduga ataupun tidak diinginkan. Burnout yang tinggi bisa disebabkan oleh faktor-faktor lainnya. Maslach, Schaufeli dan Leiter (2001) mengelompokkan faktor yang mempengaruhi burnout menjadi dua, yaitu faktor situasional dan faktor individual. Burnout yang tinggi pada perawat dapat disebabkan oleh hal atau faktor secara internal seperti kepribadian. Selanjutnya, tuntutan tugas sebagai perawat pun dapat menyebabkan munculnya burnout. Tidak hanya dalam menangani pasien yang menjadi orang dalam status pemantauan ataupun positif covid-19, namun selama masa covid-19 ini banyak pasien yang tercatat. Pekerjaan yang menjadi lebih padat dan tuntutan tugas ini dapat dilihat dari jumlah data di salah satu rumah sakit, dimana adanya lonjakan pasien dari bulan Juni sebanyak 872 orang dan di bulan Juli sebanyak 1.154 orang. Hal tersebut memberikan gambaran bahwa perawat bisa merasa lelah secara emosional karena beban kerja yang padat di masa penyebaran wabah covid-19 ini. Perawat yang harus menjalankan tugasnya dalam masa covid- 19 ini perlu merasa aman ketika berhadapan dengan pasien baik itu dalam status pemantauan ataupun pasien biasa. Hal tersebut dikarenakan sesuai dengan hak seorang perawat dimana mereka harus merasa terlindungi dalam setiap proses kerja.

Penelitian ini memiliki limitasi secara metodologi yaitu tidak mengontrol faktorfaktor dan variabel lain selain iklim organisasi. Selanjutnya, dalam hal sampel dan representative hasil data, dimana sebaiknya ada faktor-faktor demografi lainnya selain usia, jenis kelamin dan status pernikahan yang dapat digunakan dalam membatasi penelitian ini. Mengenai waktu dalam menyebarkan kuesioner pun menjadi salah satu limitasi dalam penelitian ini. Karena mengingat adanya wabah covid-19 menjadi kesulitan tersendiri dalam mencari responden jika dilakukan dengan mendatangi langsung perawat ke 
Rumah Sakit setempat.

Saran untuk pihak rumah sakit untuk dapat melakukan penjadwalan rutin coaching dan peer-counseling bagi para perawat agar dapat memantau dan menanggulangi muncul dan bahaya karena tingkat burnout yang tinggi. Juga untuk perawat agar lebih mengenal diri sendiri dalam menjalankan pekerjaan, menanggulangi stress dan menyalurkannya. Untuk penelitian selanjutnya, disarankan untuk meneliti faktor-faktor internal yang menjadi penyebab munculnya burnout.

\section{DAFTAR PUSTAKA}

Asi, S. P. (2014). Pengaruh Iklim Organisasi Dan Burnout Terhadap Kinerja Perawat RSUD Dr. Doris Sylvanus Palangka Raya. Jurnal Aplikasi Manajemen, 11(3), 515-523.

Cherniss, C. 1987. Staff Burnout ; Job Stress In Human Services. London : Sage Publications.

Goad, W. S (2016). Nurse Burnout: Overcoming Stress In Nursing.

Hoskins, K. N. 2013. The Possible Role Of Burnout In Nursing Errors. Orlando

Kassem, A. H., \& Gaber, H. (2015). Organizational Climate And Its Impact On Nurse's Job Empowerment At Main Mansoura University Hospital And Urology And Nephrology Center. IOSR Journal Of Nursing And Health Science (IOSRJNHS), 4(2), 40-48.

Kusnanto. 2003. Profesi Dan Praktik Keperawatan Profesional. Jakarta : EGC

Maslach C, Jackson SE, Leiter MP. 1996. Maslach Burnout Inventory Manual. Palo Alto, CA: Consult. Psychol. Press. 3rd ed.
Maslach, C \& Schaufeli, W.B 1993. Historical And Conceptual Development Of Burnout. In Professional Burnout: Recent Developments In Theory And Research. Washington DC: Taylor \& Francis.

Maslach, C., Leiter, M. P., \& Schaufeli, W. B. (2001). Job Burnout. Annual Review Psychology, 52, 397-422.

Peña-Suárez, E., Muñiz, J., Fonseca-Pedrero, E., \& García-Cueto, E. (2013). Assessing organizational climate: Psychometric properties of the CLIOR Scale. Psicothema, 25(1), 137-144.

Poghosyan, L., Aiken, L. H., \& Sloane, D. M. (2009). Factor structure of the Maslach burnout inventory: an analysis of data from large scale cross-sectional surveys of nurses from eight countries. International journal of nursing studies, 46(7), 894-902.

Robbins, Stephen P. dan Timothy A. Judge. (2008). Perilaku Organisasi Edisi ke-12, Jakarta: Salemba Empat.

Sahrah, A. (2018). Burnout Perawat Perempuan Ditinjau Dari

Iklim Organisasi. Psycho Idea, 15(2), 88-97.

Suma'mur. 2009. Higiene Perusahaan Dan Kesehatan Kerja (Hiperkes). Jakarta: CV. Sagung Seto.

Triguni. 2000. Kepemimpinan Dalam Manajemen. Jakarta: Raja Grafind.

Worldometer, 2020. "Covid-19 Coronavirus Pandemic", Https://Www.Worldometers.Info/C oronavirus/, Diakses Pada Mei 2020 